\title{
Technology of soil stabilization with cement- sand grouting mortar with optimal aggregate grading
}

\author{
Tatyana Zhilkina ${ }^{1, *}$, Stanislav Sychugov ${ }^{2}$, Alexander Gumeniuk ${ }^{2}$, Rimantas Mackevicius ${ }^{3}$, \\ Vadim Turchin ${ }^{2}$, Vladimir Vasilev ${ }^{2}$, Marat Zakirov ${ }^{2}$, and Alexander Ilinsky ${ }^{2}$ \\ ${ }^{1}$ Moscow State University of Civil Engineering, Yaroslavskoye Shosse, 26, Moscow, 129337, Russia \\ ${ }^{2}$ Izhevsk State Technical University. M. T. Kalashnikov (ISTU), Studencheskaya street, 7, Izhevsk, \\ 426069, Russia \\ ${ }^{3}$ Vilnius Gediminas Technical University (VGTU), Sauletekio al. 11, Vilnius, LT-10223, Lithuania
}

\begin{abstract}
This article studies technological, physical and technical properties and corrosion resistance of cement-sand slurry. Comparative data of the strength of test samples made on mortars of equal mobility with a composition of 1:1 (C: S) using river sand with fineness moduli (Mf): 1.50; $1.35 ; 1.25$, showed the best results in the latter case. The use of the "Mylonaft M1" plasticizer in the solution in an amount of $0.5 \%$ of the mass of the cementing with sand with $\mathrm{Mf}=1.25$ allowed to keep the mobility of $200 \mathrm{~mm}$ at $\mathrm{W} / \mathrm{C}$ ratio $=0.6$ without loss of the mixture homogeneity. Investigation of the corrosion resistance of sample mortars with the introduction of $1 \% \mathrm{Na} 2 \mathrm{SO} 4$ into it during the process of its preparation made it possible to achieve stability in aggressive sulfate media at low $(\mathrm{T}=$ $20^{\circ} \mathrm{C}$ ) and normal temperatures $\left(\mathrm{T}=5^{\circ} \mathrm{C}\right)$. In order to mechanize the work on strengthening the loess soils with cementing slurry the traditional equipment used in the production (stationary solution station with a compressor and a pump) has been compared with the advanced mobile unit UNB-125 $\times 50$ SO on the basis of KamAZ 363501 .
\end{abstract}

\section{Introduction}

The heterogeneous condition of soils at the base of construction and their uneven compression due to poor compaction [1] or frequent water intrusion result in the uneven development of the foundation sediments and their further destruction [2]. Restoration of the efficiency of subgrade soil, ensuring the reliability of buildings and constructions with injection stabilization is related to high material expenses. Reduction of the cost of work is an actual engineering challenge, which can be solved by using domestic inexpensive materials used for the preparation of injection composition [3], the introduction of advanced technologies and mechanization tools.

The choice of technology and methods of the soil stabilization depends on the engineering challenges that determine the formulation of injection composition. A common method of

\footnotetext{
* Corresponding author: tagilkina@mail.ru
} 
soil stabilization is cementation using hydraulic fracturing of soil layers, where the use of compositions based on cement with various mineral and chemical additives is efficient. The cost of $1 \mathrm{~m}^{3}$ of dry mixture of injection composition depends on the types: of the used (mineral or organic) binder, chemical additives [4] and mineral fillers [5]. Highly effective binders in injection compositions are: aluminate, sulfoaluminate [6], ferrite-containing [7], expansible lightweight, weighted, low hygroscopic and belite-diatomaceous earth oil-well cements [8]. The cost of such cements is high and not all regions of the country have them. Interest is attracted by slag, ash and sand cements, the raw materials for which are the existing waste of the fuel and metallurgical complex and natural (quarry and river) sand [9-13]. Injection compositions based on such cements have a lower cost.

The authors of the paper have studied a cement-sand grouting mortar containing additives: sodium sulfate $\left(\mathrm{Na}_{2} \mathrm{SO}_{4}\right)-1 \%$ and "Mylonaft $\mathrm{M}_{1}$ " - $0.5 \%$ (of cement weight), introduced to improve the corrosion resistance of cement stone, for the purpose of use as an injection composition. The "The School No. 5 in Malgobek ", the Republic of Ingushetia was the object. Soil stabilization was carried out by cementation with hydraulic fracturing.

\section{Materials and research methods}

\subsection{Materials}

Initial materials for the preparation of a grouting mortar were: Cem I $32.5 \mathrm{~N}$ portland cement of the Iskitim cement plant, the mineralogical composition of which is presented in the Table 1; River quartz sand that complies with the requirements of GOST 8736-2014; Sodium sulfate $\left(\mathrm{Na}_{2} \mathrm{SO}_{4}\right)$ technical, complying with the requirements of GOST 21458-75; Water, complying with the requirements of GOST 23732-2011; Plasticizing additive "Mylonaft $\mathrm{M}_{1}$ ", complying with the requirements of the STO 10105154-001-2009.

Table 1. Chemical and mineralogical characteristics of cement.

\begin{tabular}{|c|c|c|c|c|c|c|c|c|c|c|c|c|}
\hline \multirow[b]{2}{*}{ Binder } & \multicolumn{12}{|c|}{ Content, $\%$} \\
\hline & $\mathrm{CaO}$ & $\mathrm{SiO}_{2}$ & $\mathrm{Al}_{2} \mathrm{O}_{3}$ & $\mathrm{Fe}_{2} \mathrm{O}_{3}$ & $\mathrm{MgO}$ & $\mathrm{SO}_{3}$ & $\begin{array}{c}\mathrm{Na}_{2} \mathrm{O} / \\
\mathrm{K}_{2} \mathrm{O}\end{array}$ & $\mathrm{FeO}$ & $\mathrm{C}_{3} \mathrm{~S}$ & $\mathrm{C}_{2} \mathrm{~S}$ & $\mathrm{C}_{3} \mathrm{~A}$ & $\mathrm{C}_{4} \mathrm{AF}$ \\
\hline $\begin{array}{l}\text { Cem. I } \\
32.5 \mathrm{~N}\end{array}$ & $\begin{array}{c}64.0- \\
66.0\end{array}$ & $\begin{array}{l}20.5- \\
21.5\end{array}$ & $4.5-5.3$ & $4.5-5.0$ & $\begin{array}{c}2.5- \\
3.5\end{array}$ & $\begin{array}{l}0.5- \\
1.0\end{array}$ & $\leq 1.0$ & $\leq 0.1$ & $\begin{array}{r}64.0- \\
66.0\end{array}$ & $\begin{array}{l}10.0- \\
11.0\end{array}$ & $5.0-7.0$ & $\begin{array}{c}12.5- \\
13.5\end{array}$ \\
\hline
\end{tabular}

Selection of the composition of the grouting mortar was carried out according to [4], taking into account the physicochemical properties of the soils to be stabilized. The main criterion for ensuring the penetration of the injection composition into the soil thickness was the mobility of the slurry, determined by flow the AzNII and taken at least $200 \mathrm{~mm}$. In order to prevent delaminatability of the mortar containing the plasticizer, the amount of fine sand fraction - residues on the sieve 0.16 and 0.315 was additionally increased by $3-6 \%$ and $7-10$ $\%$, respectively. The ratio between cement and sand was taken $1: 1$. River sand was prepared with three fineness moduli $\left(\mathrm{M}_{f}\right): 1.25 ; 1.35 ; 1.50$. The mixture of cement and sand was mixed in dry form, followed by further addition of water until paste of plastic consistency was obtained. The $\mathrm{W} / \mathrm{C}$ ratio varied within the range of $0.60-0.65$, taking into account the content of the plasticizing additive. Sodium sulfate was added to mortar mix. The mixing time of the components ranged from 3 to $5 \mathrm{~min}$. The plasticizer was added to the mortar mix in $1 \mathrm{~min}$. after the mixing began, the amount of which was assumed to be $0.5 \%$ of the cement mass.

Fluidity, homogeneity and density of the grouting mortar mix were studied. The sample cubes made of paste of plastic consistency, with a rib size of $20 \times 20 \times 20 \mathrm{~mm}$ were stored in water, at air-wet and aggressive conditions at room $\left(\mathrm{T}=20^{\circ} \mathrm{C}\right)$ and low $\left(\mathrm{T}=5{ }^{\circ} \mathrm{C}\right)$ temperatures and tested on the 7 th the 28 th day. Before testing in aggressive sulfate 
environment, the samples were held at air-humid laboratory conditions for 14 days in a desiccator [14].

\subsection{Research methods}

The sulfate resistance of the samples of a grouting mortar was studied by titration every 2 days. $5 \%$ sulfuric acid $\left(\mathrm{H}_{2} \mathrm{SO}_{4}\right)$ was used as a titrant. The accuracy of dosing of the acid for neutralization of $\mathrm{Ca}(\mathrm{OH})_{2}$ was controlled by a $150 \mathrm{MI} \mathrm{pH}$-meter [11]. The grouting mortar was tested in accordance with GOST 26798.1-96. Microscopical analysis of the cement stone of the grouting mortar and stabilized soil were performed using a microscope Olympus SZ 61 and GX 51 with 50 to 500-fold magnification.

The strength of the stabilized soil with the tested grouting mortar was determined on samples-cubes with a rib size of $20 \times 20 \times 20 \mathrm{~mm}$, which were cut from a selected soil sample while drilling at the site.

\subsection{Experimental procedure}

The preparation of cement-sand grouting mortar with the required mobility $\left(\mathrm{D}_{s f}=200 \mathrm{~mm}\right)$ is related to the need to obtain a homogeneous mixture without disintegration, which provides the qualitative performance of work. It is well known $[4,5,15]$ that cement-sand mortars on fine sand $(1.5 \leq \mathrm{Mf} \leq 2.0)$ have a greater homogeneity as a result of which the cement stone has higher density, impermeability and compressive strength. However, the developed specific surface of the filler causes the increased consumption of cement. Addition of the plasticizer "Mylonaft $\mathrm{M}_{1}$ " in the amount of $0.5 \%$ of the weight of the binder and the choice of the optimal granulometric composition of sand excluded the negative phenomenon.

The fineness modulus $\left(\mathrm{M}_{f}\right)$ was selected at the lower boundary of the fine and according to the values for very fine sands - from 1.25 to 1.50 . On the basis of earlier studies [11], the cement - sand ratio was taken as $1: 1$. The study of the sand fineness modulus for the strength properties of a grouting mortar (Fig.1, a) showed that the greatest strength was achieved with sand at $\mathrm{M}_{f}=1.25$. From 7 th to 28 th day, the strength increased by $11 \%$ - from $6.22 \mathrm{MPa}$ to 6.87 MPa and was maximum.

a)

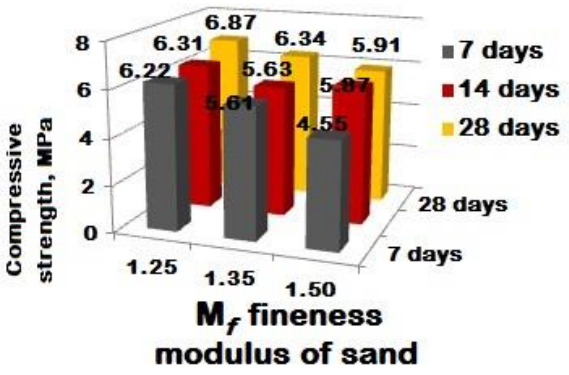

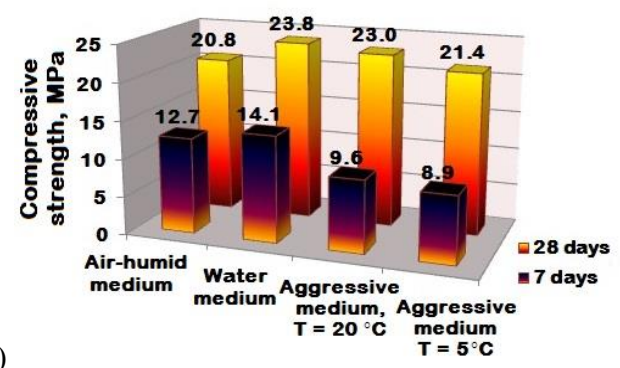

b)

Fig. 1. The strength of a cement-sand grouting mortar with a composition of $1: 1(\mathrm{C}: \mathrm{S})$ : (a) depending on the used sand fineness modulus; (b) - the optimal formulation with the dosage of the plasticizing additive "Mylonaft $\mathrm{M}_{1}$ " in the amount of $0.5 \%$ and $\mathrm{Na}_{2} \mathrm{SO}_{4}$ in the amount of $1 \%$ of the binder mass.

The samples of all the studied fineness moduli showed an increase in strength on the 28th day. This fineness module of the sand was used to prepare the grouting mortar. Visual analysis of the samples stored in aggressive environments on the 28th day did not reveal their destruction, which indicated the effectiveness of use of $1 \% \mathrm{Na}_{2} \mathrm{SO}_{4}$ additive [12]. The test 
results (Fig. 1, b) showed the highest strength when stored in water, the value of which corresponds to $23.8 \mathrm{MPa}$ (the grade of solution is M200). The coefficient of strength reduction is determined by the formula:

$$
\mathrm{KC}=\frac{\mathrm{AC}_{28}}{\mathrm{~B}_{28}}=\frac{21.4 \mathrm{MPa}}{23.4 \mathrm{MPa}}=0.90
$$

where $\mathrm{AC}_{28}$ - ultimate strength $R_{\text {com }}$, $\mathrm{MPa}$ of the sample, tested after being in an aggressive environment of the $1 \mathrm{~N}$-th aqueous solution of sodium sulfate for 28 days; $\mathrm{B}_{28}$ is the ultimate strength $R_{\text {com }}$, MPa of the sample tested after being in the aqueous environment for 28 days. The consumption of components, composition, technological and mechanical properties of the composition are presented in the table 2 .

Table 2. Properties of cement-sand grout \& consumptions of components to $1 \mathrm{~m}^{3}$.

\begin{tabular}{|c|c|c|c|c|c|c|c|c|}
\hline \multicolumn{5}{|c|}{ Consumptions of components } & \multicolumn{4}{|c|}{ Properties } \\
\hline \multirow[b]{2}{*}{$\begin{array}{l}\mathrm{C}, \\
\mathrm{kg}\end{array}$} & \multirow[b]{2}{*}{$\begin{array}{l}\mathrm{S}, \\
\mathrm{kg}\end{array}$} & \multirow{2}{*}{$\begin{array}{c}\mathrm{W} \\
1\end{array}$} & \multirow[b]{2}{*}{$\begin{array}{l}\mathrm{Pl}, \\
\mathrm{kg}\end{array}$} & \multirow[b]{2}{*}{$\begin{array}{c}\mathrm{Na}_{2} \mathrm{SO}_{4} \\
\mathrm{~kg}\end{array}$} & \multicolumn{2}{|c|}{ Technological } & \multicolumn{2}{|l|}{ Mechanical } \\
\hline & & & & & $\begin{array}{c}\text { Mortar } \\
\text { density, } \mathrm{kg} / \mathrm{m}^{3}\end{array}$ & \begin{tabular}{|c|} 
Flow \\
diameter, $\mathrm{mm}$
\end{tabular} & $\begin{array}{c}\text { Compressive } \\
\text { strength, }\left(R_{\mathrm{c}}^{28}\right), \mathrm{MPa}\end{array}$ & КС \\
\hline 884.9 & 884.9 & 531.0 & 4.42 & 8.84 & 1130 & 200 & 21.4 & 0.90 \\
\hline
\end{tabular}

The analysis of the microstructure of the test sample of the grouting mortar (Fig.2) showed absence of destructive processes in the cement stone after being in aggressive environment for 28 days. Pores on the cleavage of samples of 0.28 to $0.38 \mathrm{~mm}$ which are conditionally closed can be seen quite distinctly in the photos with different magnifications. A relatively tight binding between the binder and the filler (the upper micrographs in Fig. 2) has been observed, which contributes to the increase in the strength of the samples held in an aggressive environment at room and low temperatures, which is achieved using the additive "Mylonaft $\mathrm{M}_{1}$ " and selecting the optimal grading of very fine quartz sand. The use of $1 \%$ $\mathrm{Na}_{2} \mathrm{SO}_{4}$ in the composition of a grouting mortar increases its corrosion resistance in a sulfate environment, which is also pointed out in papers $[15,16]$.

a)
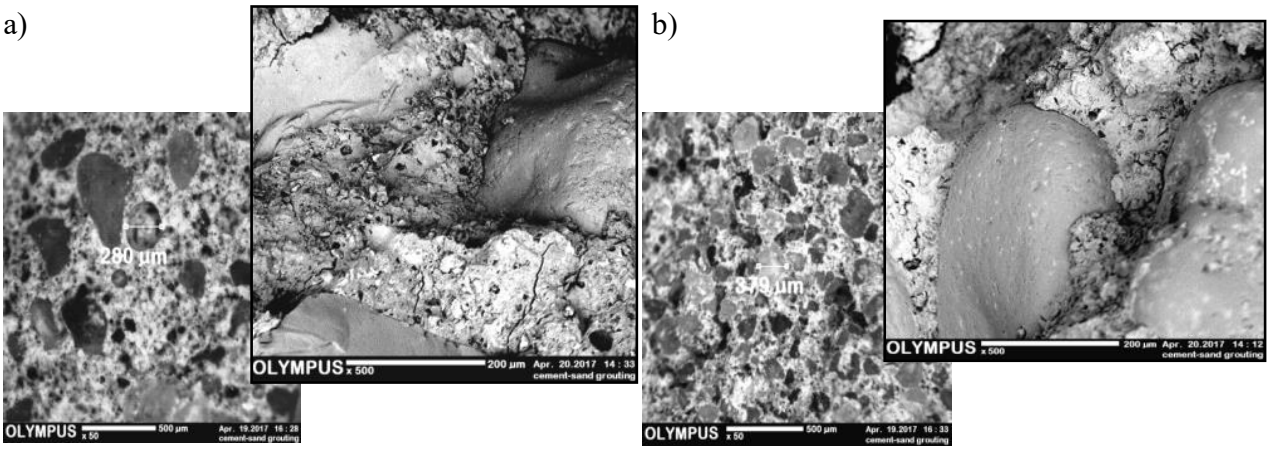

Fig. 2. The microstructure of the cement stone of the sample of a grouting mortar tested in an aggressive environment: (a) - room temperatures $\left(\mathrm{T}=20^{\circ} \mathrm{C}\right)$; (b) - low temperatures $\left(\mathrm{T}=5^{\circ} \mathrm{C}\right) .50$ and 500-fold magnification.

Thus, the use of very fine sand with $\mathrm{M}_{f}=1.25$ in the composition of a grouting mortar together with the plasticizing additive "Mylonaft $\mathrm{M}_{1}$ " in an amount of $0.5 \%$ of the binder mass makes it possible to exclude the water segregation due to disintegration; Preserve the required mobility of the mortar for the injection works. 


\section{Technology of cement-sand grouting solutions}

The present work considers the technology of the stabilization of loess soils for bases under the pile foundation of the "School No. 5 in Malgobek", the Republic of Ingushetia [14, 17]. A method of cementation with hydraulic fracturing of loess formation was selected taking into account the construction properties of the soil $[16,18]$. To improve the effect of soil compaction by injection of a mortar with a time-controlled increase in viscosity and structural strength, it is continuously required to increase the pressure, which has positive effect on its strength properties [19].

For the intrusion of grouting mortar, a complex, including a self-propelled mobile drilling rig UBS-50A with a feed screw with a diameter of $400 \mathrm{~mm}$ and a mixing mortar station with a compressor was used. The operating pressure when mortar was fed into injectors ranged from 10 to 15 bar (1.0-1.5 MPa). Before installing the injectors, a lubricating liquid, which is prepared in the form of an aqueous solution "Mylonaft $\mathrm{M}_{1}$ " with 1:30 composition, is poured into the well. Well injection was performed by pinch bars equal in size to the length of the perforated part of the $1.5 \mathrm{~m}$ injector. The grouting mortar was injected into the lower zone and under the end of the pile with a break in the soil integrity with a maximum pressure of 1.5 MPa.

The total volume of fixed loess soil according to the data of [15] by the chosen method was $34.95 \mathrm{~m}^{3}$, which corresponds to the consumption of the grouting mortar of $5.97 \mathrm{~m}^{3}$. Thus, $1 \mathrm{~m}^{3}$ of the grouting mortar is stabilized with an average of $5.85 \mathrm{~m}^{3}$ of loess soil at a pressure of $1.5 \mathrm{MPa}$.

In addition to the above-mentioned used complex of machines, another option was considered - the use of a universal unit UNB-125 $\times 50$ SO produced by Izhneftemash OJSC in Izhevsk, a partner of the Construction and Road Machinery Department of the ISTU, of the intended for transportation of powdery materials (cement, grouting mixtures, etc.), mechanically controlled feeding of these materials with screw conveyors (feed screws) when preparing grouting mortars, during their accumulation and mixing, injection of various liquid media during well cementing during the process of drilling, development and well-workover operations and preflush and overflush operations on oil and gas wells. (Fig.3). The technical characteristics of the unit are presented in the table 3 [16].

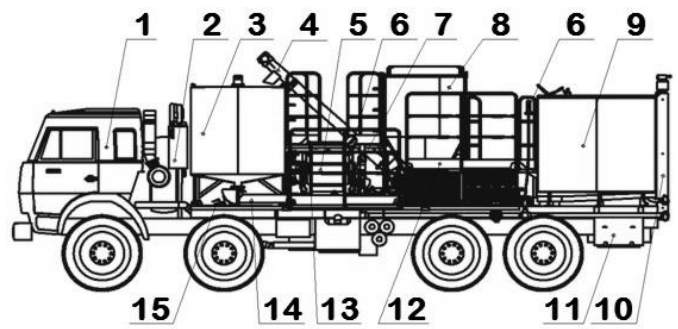

Fig. 3. Pumping plant UNB- $125 \times 50$ CO: 1 - chassis of KamAZ car, 2 - hydraulic tank, 3 - mixing tank, 4 - feeding screw, 5 - pump NTP-175x40, 6 - manometer, 7 - safety valve, 8 - bunker, 9 - gaging tank with bottom valves, 10 - exhaust, purging, heating system, 11 - rack, 12 - tiltable platforms, 13 operator's platforms, 14 - plant manifold, 15 - sampler.

Despite the fact that this unit is designed to perform mainly plugging operations on oil and gas wells, taking into account its technical characteristics, it can successfully replace the traditional set of technological equipment used for injection works for soil stabilization.

The versatility of this unit consist in the fact that it can transport, prepare, feed ready grouting mortars with the screw conveyors and inject them with a single transport device. 
Table 3. Technical characteristics of machine.

\begin{tabular}{|c|c|c|}
\hline № & Parameter & Value \\
\hline 1 & $\begin{array}{l}\text { High pressure pump } \\
\text { - diameter of the plunger, mm } \\
\text { - gear ratio of the built-in reducing gearbox } \\
\text { - maximum power, } \mathrm{hp}(\mathrm{KW}) \\
\text { - maximum pressure, } \mathrm{MPa}\left(\mathrm{kgf} / \mathrm{cm}^{2}\right) \\
\text { - maximum ideal flow, } \mathrm{dm}^{3} / \mathrm{s}(\mathrm{l} / \mathrm{min}) \\
\end{array}$ & $\begin{array}{c}\text { NTP-175 } \\
90,100,110 \text { и } 125 \\
5.06 \\
175(129) \\
50(500)-4(40)^{*} \\
2,03(121,8)-24.54(1472.4)^{*} \\
\end{array}$ \\
\hline 2 & $\begin{array}{l}\text { Bunker for dry mixtures } \\
\text { - volume, } \mathrm{m}^{3} \text {, not less than } \\
\text { - mass of the transported material, } \mathrm{t} \text {, not more than } \\
\text { - cement unloading } \\
\text { - screw drive }\end{array}$ & $\begin{array}{c}4 \\
5 \\
\text { worm } \\
\text { hydraulic }\end{array}$ \\
\hline 3 & $\begin{array}{l}\text { Mixing tank with an agitator } \\
\text { - volume, } \mathrm{m}^{3} \text {, not less than } \\
\text { - agitator } \\
\text { - type of agitator } \\
\text { - drive of the agitator }\end{array}$ & $\begin{array}{c}5.5 \\
2 \text { pcs. } \\
\text { Vertical blade } \\
\text { hydraulic }\end{array}$ \\
\hline 4 & $\begin{array}{l}\text { Gaging tank for water } \\
\text { - volume, } \mathrm{m} 3 \text {, not less than }\end{array}$ & 6 \\
\hline 5 & type of agitator & $\begin{array}{l}\text { Feed dry material into the grouting } \\
\text { fluid }\end{array}$ \\
\hline
\end{tabular}

The required set of equipment is mounted on the frame and installed on the chassis of the KamAZ 63501 car of increased cross-country capacity with an engine power of $260 \mathrm{~kW}$ and a wheel formula of $8 \times 8$ : high pressure pump NTP-175, dry mix bunker, gaging water tank, mixing tank with mixing blades, water feeding pump, transmission, manifold, and other supplementary equipment. The pump is driven from the traction engine of the automobile chassis. The operating modes of the pump (the developed pressure in $\mathrm{MPa}\left(\mathrm{kgf} / \mathrm{cm}^{2}\right)$ and the feed in $\left.\mathrm{dm}^{3} / \mathrm{s}(1 / \mathrm{min})\right)$ depend on the engine shaft speed and can be changed if necessary. Also, plungers of the pump with diameters from 90 to $125 \mathrm{~mm}$ can be replaced. (See table 3 ). The unit is designed to operate in a moderately cold macroclimatic region in accordance with GOST 16350-80.

When there is a large amount of work, the unit can work completed with quickly assembled dismountable batching plant or mobile concrete plants (MCP). A comparative analysis of the characteristics of the UNB-125 $\times 50 \mathrm{SO}$ unit with a complex of a batching station, a mixer, a compressor and a pump with a manometer, injecting grouting mortars, showed a significant advantage of the UNB-125 $\times 50 \mathrm{SO}$. The comparable parameters were: pressure on the mortar mix $p, \mathrm{MPa}$, practical productivity $P_{p}, \mathrm{~m}^{3} / \mathrm{h}$, supplied power $N, \mathrm{~kW}$, the data are presented in the table 4.

Table 4. Comparative \& estimated data of machines.

\begin{tabular}{|c|c|c|c|}
\hline \multirow{2}{*}{ Machines } & \multicolumn{3}{|c|}{ Parameters } \\
\cline { 2 - 4 } & $\boldsymbol{p}, \mathrm{MPa}$ & $\boldsymbol{N}, \mathrm{kW}$ & $\boldsymbol{P}_{\boldsymbol{p}}, \mathrm{m}^{3} / \mathrm{h}$ \\
\hline UNB-125 $\times 50 \mathrm{CO}$ & $4.0-50.0$ & 99 & $7.3-88.3$ \\
\hline $\begin{array}{c}\text { Complex of a batching station, a mixer, a compressor } \\
\text { and a pump with a manometer }\end{array}$ & 10.0 & 10.6 & 2.4 \\
\hline
\end{tabular}

Thus, the data in Table 4 allow us to conclude that it is advisable to use the UNB-125 $\times 50$ SO unit in the technology plugging operations. The comparative characteristics of the operating parameters $(\mathrm{p}, \mathrm{N}, \mathrm{PP})$ of the UNB-125 $\times 50 \mathrm{SO}$ are several times higher than those 
of the traditional equipment used during performance of the works: the pressure on the concrete mixture is up to 5 times; Power - 9.3 times; Productivity - up to 36.8 times.

\section{The researching of soils properties}

Investigation of the mechanical properties of loess soils stabilized by cementation with the help of hydraulic fracturing with cement-sand grouting mortars showed satisfactory quality of performed work (table 5).

Table 5. Mechanical characteristics of loess soil.

\begin{tabular}{|c|c|c|}
\hline \multirow{2}{*}{ Type of soil } & \multicolumn{2}{|c|}{ Parameters } \\
\cline { 2 - 3 } & $\boldsymbol{R}, \mathrm{MPa}$ & $\boldsymbol{\gamma}^{*}, \mathrm{~kg} / \mathrm{m}^{\mathbf{3}}$ \\
\hline Before stabilization & 0.35 & 1520 \\
\hline After stabilization & 1.30 & 1570 \\
\hline
\end{tabular}

* The value is given as the arithmetic average of six samples

Comparative data on the density of loess soils before and after stabilization by a grouting mortar showed an increase in the density of the soil skeleton by $3.2 \%$, and in the strength by 3.7 times.

\section{Conclusions}

Comprehensive research carried out by the employees of the MSUCE, ISTU, together with VGTU, aimed at improving the technology of preparation and application of grouting mortars when stabilizing loess soils, led to the following conclusions:

- the use of local materials (washed river quartz sand) and inexpensive domestic chemical additives ("Mylonaft $\mathrm{M}_{1}$ ") makes it possible to obtain high quality grouting mortars that are noninferior in strength and corrosion resistance to foreign analogues;

- grouting mortars prepared on sand with $\mathrm{M}_{f}=1.25$ with a composition (C:S) 1:1 have a M200 strength grade. The best environment for strength increase is water;

- decrease in the binder (cement) consumption and increase of the corrosion resistance of the mortar in an aggressive environment is possible using a complex method of selecting the optimal granulometric composition of sand, using $1 \% \mathrm{Na}_{2} \mathrm{SO}_{4}$ and $0.5 \%$ of the plasticizer "Mylonaft $\mathrm{M}_{1}$ " with mobility retention;

- reduction of the terms of performance of the work when stabilizing soils by injection compositions on the basis of cement-sand grouting mortars is possible using the autonomous mobile unit UNB-125 $\times 50 \mathrm{SO}$, and in the case of a large volume of work - completed with a stationary or mobile mortar plant.

\section{References}

1. M. Mikolainis, M. Ustinovičius, D. Sližyte, T.A. Zhilkina, Engineering Structures and Technologies 8(2), 79-84 (2016)

2. R.A. Mangushev, V.D. Karlov, Foundation Engineering (ACU, Moscow-St. Petersburg, 2014)

3. T.A. Zhilkina, Materials of the 10th International Conference Modern Building Materials, Structures and Techniques 10, 1186-1190 (2010)

4. Yu.M. Bazhenov, V.F. Korovyakov, G.A. Denisov, Technology Of Dry Building Mixes: Study Guide (ACU, Moscow, 2011)

5. L.D. Chumakov, Technology of Concrete Fillers: Study Guide (ACU, Moscow, 2011) 
6. T.V. Kuznetsova, Production and application sulfoaluminate Cements. Stroitel nye Materialy, 3 (2010)

7. Yu.R. Krivoborodov, A. Yu. Burlov, I.Yu. Burlov, The Use of Recoverable Resources for Cement Production. Stroitel nye Materialy, 2 (2009)

8. L.A. Kroychuk, Russian Cement Industry. Stroitel 'nye Materialy 1, (2005)

9. A.M. Sergeev, Use of Energy Industry Wastes in Construction Industry (Budivelnyk, Kiev, 1984)

10. P.V. Krivenko, E.K. Pushkareva, Cement and concretes based on ashes and slags (IPK Express-Polygraph, Kiev, 2012)

11. A.N. Gumeniuk, T.N. Ivanova, Intell. Sist. in Prod. 1, 15 (2017)

12. R. Mackevicius, D. Slizyte, T. Zhilkina, Procedia Engineering 172, 681-684 (2017)

13. V. Marčiulatis, D. Sližyte, R. Mackevičius, T.A. Zhilkina, Engineering Structures and Technologies 7(3), 140-145 (2015)

14. T.N. Ivanova, V.V. Turchin, Procedia Engineering, 172 (2017)

15. L.I. Dvorkin, O.L. Dvorkin, Special Concretes (Infra-Engineering, Moscow, 2012)

16. V.V. Turchin, L.V. Yudina, Intell. Sist. in Prod. 2, 20 (2012)

17. V. Turchin, L. Yudina, S. Sychugove, T. Zhilkina, R. Mackevicius, S. Danute, IOP Conference Series: Earth and Environmental Science, Energy Management of Municipal Transportation Facilities and Transport, 012205 (2017)

18. M.N. Ibragimov, Found. Engin. and Soil Mech., 2 (2015)

19. L.V. Yudina, V.V. Turchin, Y.N. Baburin, Materials of the 10th International Conference, Modern Building Materials, Structures and Techniques 10, 1116-1120 (2010) 